KS. RYSZARD KNAPIŃSKI

\title{
ZNAK POJEDNANIA
}

Jesteśmy zaproszeni do przeżycia jednej z tajemnic ludzkiego życia tajemnicy pojednania. Do takiej refleksji zaprasza nas wystawa rzeźby sakralnej Gustawa Zemły, profesora Akademii Sztuk Pięknych w Warszawie.

ZNAK POJEDNANIA przywołuje na zasadzie opozycji myśl o tym, co jest jego zaprzeczeniem. Przeciwieństwem czego bywa pojednanie? obrazy... niewierności... zdrady... przemocy... gwałtu... wojny... Tak. Choć w przytoczonych pojęciach widoczna jest eskalacja zawartości elementu zła, to nie wyczerpują one wielkości problemu. W twórczym przeżyciu artysty, tak jak w wizji prorockiej, staje się widoczna summa obrazy, niewiernosci, zdrady itd. Z płaszczyzny uniwersalnej geniusz artysty przenosi ciężar problematyki zła i naprawy na płaszczyznę transcendentną. I wtedy każda pojedyncza zdrada, każdy przejaw przemocy, stają się składnikiem wielkiego grzechu niewierności, w którym echem powraca pierwotne non serviam! A więc w tle pozytywnych rozważań o pojednaniu przypomina się dramat ODEJŚCIA. Przez wieki idzie Kainowe plemię.

Owego misterium iniquitatis dotyka Gustaw Zemła w poszarpanych szrapnelami kul, w wypalonych ogniem wojen formach w takich rzeźbach jak Polegli niepokonani, Spalona Warszawa, Rozstrzelani. Artysta wypracował własny język tworzenia rozstrzępionej, jak potargany w boju sztandar, formy, która mokra od znoju otula wypalony kadłub człowieka, domu, miasta... A może raczej kładzie się jak wielka blizna na ruszt martyrium. I dlatego spod owitych mokrą tkaniną kikutów, upadłego pod ciężarem megaprzemocy niewinnego Abla, wydobywa się nowy harmonijny kształt formy symbolizującej życie. Jak Nike $z$ Samotraki zwycięski duch uwalnia się z okowów materii i trwa przemieniony. Nawet nie trzeba dodawać mu skrzydeł, stał się symbolem Zwycięstwa. Oznacza życie, które już nie ma końca.

Wielkie dzieła Mistrza stanowią oddzielny rozdział w dziejach współczesnej sztuki polskiej (Pomnik Powstańców Ślaskich, pomnik Polegli Niepokona$n i$, pomnik Czynu Polaków i in.). Są one przykładami rzeźbiarskiego kunsztu Gustawa Zemły, w których tematyka laicka staje się nośnikiem treści metafi- 
zycznych: odwiecznego pragnienia człowieka, by żyć nieśmiertelnie. Wyrażają to symbolicznie przetworzone motywy skrzydeł. Ideę tę artysta przejął od wielkich mistrzów klasycznej i helleńskiej plastyki, którymi się przed laty fascynował.

Ale Zemła nie jest deistą ani kimś, kto „wierzy w coś wyższego”. Bez obłudnego udawania wyznaje swoją przynależność do Kościoła. To, co jest przedmiotem jego codzięnnego zmagania się, mozolnie rozłożone w czasie, przybiera rzeźbiarską formę osobistego Credo artysty. Dlatego jego realizacje, wyrosłe z głębokiego humanizmu, pogrążonego w refleksji nad dramatem ludzkich losów, przeobrażają się w chrześcijańsko rozumiane Misterium Odkupienia. W tym dziele, do spełnienia którego Bóg zaprosił człowieka, artysta ukazuje ludzi jako żertwę ofiarną. Widać to w cyklu przypominającym ofiary Oświęcimia, zadedykowanym świętemu Maksymilianowi Kolbe. Te Oświęcimskie krzyże są tak bardzo ludzkie. Pokazują próbę przezwyciężenia hekatomby zła poprzez sumę ludzkiego cierpienia. Ale tyle ludzkich istnień złożonych na szali niewinności nie zdołało przeważyć ciężaru szatańskiego opętania manią eksterminacji innych, by stworzyć Lebensraum dla czystej rasy. Pozbawione ludzkiego oblicza kadłuby z Krzyży Oświęcimskich to niekanonizowani święci.

Jednakże rzeźbiarz nie zatrzymał się na wyrażeniu ludzkiego bólu. W metalowych lub metalizowanych kadłubach odciska się obraz Ukrzyżowanego Chrystusa. I tak oto ofiara ludzkości zostaje konsekrowana poprzez mistyczny udział w Ofierze Syna Bożego. W roku 1982 powstała pierwsza monumentalna rzeźba Ukrzyżowanego do kościoła pod wezwaniem św. Maksymiliana Kolbego w Krakowie - Mistrzejowicach. Potem przyszły inne realizacje: Warszawa Krucyfiks do grobu księdza Jerzego Popiełuszki, Katowice - kościół Podwyższenia Krzyża, Płock - Seminarium Duchowne i wiele innych. Ostatnią z nich jest Ukrzyżowany do kaplicy w konwikcie przy KUL.

Nie jest tylko tak, że to artysta rzeźbi Chrystusa. Będąc przyjacielem Gustawa obserwuję z bliska, przez co najmniej dziesięć lat, jego zmagania $\mathrm{z}$ wielkimi tematami sakralnej sztuki i widzę jak dokonuje się zwrotny proces: oto Chrystus rzeźbi i kształtuje jego samego. Czyż nie było podobnie w metamorfozie życiorysu patrona rzeźbiarzy, jakim jest Michał Anioł?

Stajemy przed wyborem prac, dla których kluczem stało się hasło: Znak pojednania. W takịm ujęciu oglądane rzeźby podsuwają refleksje o dramacie ludzkości pozytywną perspektywą. Każde ludzkie cierpienie, nawet to największe, nie idzie na marne i nigdy nie świadczy o zwycięstwie jego sprawców, ale będąc włączone w ofiarę Chrystusa zostaje przemienione i bierze udział w dziele Odkupienia. Nie przestając być znakiem cierpienia, staje się ZNAKIEM POJEDNANIA. 